\title{
Pengaruh Pemberian Madu pada Diare Akut
}

\author{
Sofyan Cholid, ${ }^{*}$ Budi Santosa, * Suhartono** \\ *Bagian Ilmu Kesehatan Anak FK UNDIP/RS Dr Kariadi, Semarang \\ **Bagian Kesehatan Lingkungan Fakultas Kesehatan MasyarakatUniversitas Diponegoro, Semarang
}

\begin{abstract}
Latar belakang. Diare masih merupakan masalah kesehatan utama di Indonesia, tahun 2003 angka kesakitan diare meningkat menjadi 374 per 1.000 penduduk dan episode pada balita 1,08 kali per tahun, meningkat dibandingkan tahun 1996. Hasil studi laboratorium dan uji klinis, madu murni memiliki aktivitas bakterisidal yang dapat melawan beberapa organisme enteropathogenic.

Tujuan. Menilai dan membuktikan bahwa pemberian madu pada pasien diare akut akan mengurangi frekuensi diare, lama rawat, dan meningkatkan berat badan

Metode. Randomized controlled trial tersamar tunggal pada 70 subyek diare akut dengan diare ringan sedang, yang dibagi menjadi 2 kelompok: kelompok suplementasi madu dan kontrol.

Hasil. Perbedaan frekuensi diare antara 2 kelompok terjadi pada hari ke-2 (IK95\% -2,87;-0,22), hari ke-4 (IK95\% -1,52;-0,08) dan hari ke-5 (IK95\% -0,99;-0,04), p<0,05. Rerata lama rawat diare cair akut pada kelompok suplementasi madu 59,46 jam $( \pm 3,89)$, kelompok kontrol 71,20 jam $( \pm 3,89)$ dengan nilai $p=0,036$ (IK95\% -22,71;-0,77). Perawatan hari ke 3 kelompok suplementasi madu mengalami kesembuhan 50\%, kelompok kontrol 25\%. Proporsi kenaikan berat badan pada kelompok suplementasi 82,9\% sedangkan kelompok kontrol $80 \%$ dengan nilai $p=0,947$.

Kesimpulan. Pemberian madu terbukti menurunkan frekuensi diare pada hari ke 2, 4, dan 5, memperpendek lama perawatan serta kesembuhan 50\% yang terjadi di hari ke-3.Tidak terdapat perbedaan kenaikan berat badan pada kedua kelompok. Sari Pediatri 2011;12(5):289-95.
\end{abstract}

Kata kunci: diare akut, madu, lama rawat.

$\Gamma$ ingkat derajat kesehatan masyarakat dapat ditentukan oleh beberapa faktor yang dapat dinilai melalui berbagai indikator antara lain seperti angka kematian bayi $(\mathrm{AKB})$, angka kematian balita (AKABA), angka kematian ibu dan tingkat gizi masyarakat. Angka kematian bayi di Provinsi Jawa Tengah Tahun 2004

\footnotetext{
Alamat korespondensi:

Dr. Sofyan Cholid, Sp.A. Bagian Ilmu Kesehatan Anak RS Dr. Kariadi Semarang, Jl Dr Sutomo 18 Semarang. E-mail:s_cholid@yahoo.co.id
}

berdasarkan hasil Survey Kesehatan Daerah 14,23 per 1.000 kelahiran hidup. ${ }^{1}$ Sedangkan AKB menurut hasil Survei Demografi Kesehatan Indonesia (SDKI) 2002-2003 terjadi penurunan yang cukup besar dari tahun 1997 sebesar 52 per 1.000 kelahiran hidup menjadi. ${ }^{2}$ Penyakit diare masih merupakan salah satu masalah kesehatan utama di Indonesia, pada tahun 2003 angka kesakitan diare 374 per 1.000 penduduk dan episode pada balita 1,08 kali per tahun. Angka kesakitan tersebut meningkat bila dibandingkan dengan hasil survei tahun 1996 yaitu 280 per 1.000 penduduk. ${ }^{2}$ Tahun 2004, diare merupakan penyakit 
dengan frekuensi kejadian luar biasa (KLB) kelima terbanyak setelah DBD, campak, tetanus neonatorum, dan keracunan makanan.

Masyarakat dunia dari berbagai budaya dan agama, telah mengenal madu sebagai jenis suplemen yang bernilai tinggi. Dari studi laboratorium dan uji klinis, madu murni memiliki aktivitas bakterisidal yang dapat melawan beberapa organisme enteropathogenic, termasuk diantaranya spesies dari Salmonela, shigela, dan E. coli. ${ }^{3}$

Uji klinis pemberian madu pada anak yang menderita gastroenteritis telah diteliti. Para peneliti mengganti glukosa $(111 \mathrm{mmol} / \mathrm{l})$ di dalam cairan rehidrasi oral yang mengandung elektrolit standar seperti yang direkomendasikan WHO/UNICEF, rata-rata waktu pemulihan dari pasien (usia 8 hari sampai 11 tahun) mengalami penurunan yang signifikan. ${ }^{4}$ Penelitian lain yang menguji madu sebagai prebiotik pada tahun 2002, membandingkan tingkat pertumbuhan Bifidobacterium spp. yang di kultur dengan memberikan madu yang berasal dari tanaman cengkeh mengalami pertumbuhan yang sama dibandingkan dengan media yang mengandung fructooligosaccharide (FOS), galactooligosaccharide (GOS), atau inulin. Namun jika dibandingkan dengan media kontrol pertumbuhan, cukup signifikan. ${ }^{5}$

Penelitian bertujuan untuk menilai pengaruh pemberian suplemen madu pada pasien diare akut, dinilai untuk lama rawat, frekuensi diare, serta menilai kenaikan berat badan. Perbedaan dengan penelitian terdahulu, madu dalam penelitian ini menggantikan komposisi glukosa dalam cairan rehidrasi oral. ${ }^{4}$

\section{Metode}

Penelitian merupakan penelitian uji klinis (randomized controlled trial) dengan tersamar tunggal, subyek penelitian dan pendampingnya tidak mengetahui kelompok penelitiannya. Dilakukan di ruang perawatan Sub-bagian Gastroenterologi Anak, Bagian Ilmu Kesehatan Anak Fakultas Kedokteran Universitas Diponegoro / RSUP Dr. Kariadi Semarang dan RSUD Ketileng Semarang. Waktu penelitian dilakukan bulan Mei 2009 sampai Januari 2010.

Kriteria inklusi, pasien diare cair akut berusia 1-5 th, tidak ada kelainan kongenital pada saluran cerna, tidak menderita penyakit penyerta yang berat atau gizi buruk, tidak dalam kondisi imunodefisiensi (pasien penyakit keganasan, dalam terapi sitostatik dan pasien yang sedang mendapat terapi kortikosteroid). Kriteria eksklusi, kadar gula darah sewaktu di atas normal, komplikasi berat akibat diare, dalam perjalanan penyakit menjadi dehidrasi berat, dan menjadi diare yang berlangsung $>14$ hari.

Pasien dibagi secara acak dengan melakukan randomisasi secara sederhana menggunakan tabel randomisasi untuk dimasukkan ke dalam salah satu dari 2 kelompok penelitian, yaitu kelompok suplementasi madu dan kelompok kontrol (tanpa suplementasi madu). Anamnesis keluhan utama dan keluhan penyerta, perjalanan penyakit dan pengobatan yang telah diberikan. Pengukuran antropometri, pemeriksaan tanda vital, derajat dehidrasi dan penyakit penyerta lainnya saat pasien mulai dirawat. Pencatatan frekuensi diare berdasarkan lembar pengamatan yang diberikan kepada orang tua atau pendamping subyek penelitian dua kali sehari (jam 06.00 dan jam 18.00) oleh peneliti. Penimbangan berat badan dilakukan satu kali perhari oleh peneliti atau seorang petugas. Lama rawat dicatat dua kali, yaitu pada saat masuk rumah sakit dan saat dinyatakan sembuh (feses menjadi lembek dan frekuensi $<3 \mathrm{x} / 24 \mathrm{jam}$ ) oleh peneliti dalam satuan waktu jam, penentuan konsitensi feses dibandingkan dengan gambar. Terapi rehidrasi dan pemberian nutrisi dilakukan sesuai protap yang berlaku.

Intervensi yang dilakukan berupa pemberian suplementasi madu secara oral oleh seorang petugas 20 g perhari, terbagi rata dalam 3 kali pemberian (pada jam 07.00, 15.00, 21.00) dengan pengenceran menggunakan aquadest steril menjadi $10 \mathrm{cc}$ pada masing-masing pemberian.

\section{Hasil}

Jumlah subyek 70 anak, terdiri dari kelompok suplementasi madu $(\mathrm{n}=35)$ dan kelompok kontrol $(\mathrm{n}=35)$. Rerata umur subyek $(18,31 \pm 0,77)$ bulan, dengan umur termuda adalah 12 bulan dan tertua 36 bulan.

\section{Karakteristik subyek penelitian}

Karakteristik subyek penelitian sebelum perlakuan berdasarkan kelompok suplementasi madu dan tanpa suplementasi madu tertera pada Tabel 1. 
Tabel 1. Karakteristik subyek

\begin{tabular}{lcc}
\hline \multirow{2}{*}{ Karakteristik } & \multicolumn{2}{c}{ Kelompok } \\
\cline { 2 - 3 } & $\begin{array}{c}\text { Suplementasi madu } \\
(\mathrm{n}=35)\end{array}$ & $\begin{array}{c}\text { Tanpa suplementasi madu } \\
(\mathrm{n}=35)\end{array}$ \\
\hline Umur (bulan, rerata, SB) & $18,31 \pm 0,77$ & $19,00 \pm 1,07$ \\
Jenis kelamin, $\mathrm{n}(\%)$ & $17(48,6)$ & $15(42,9)$ \\
$\quad$ Laki-laki & $18(51,4)$ & $20(57,1)$ \\
$\quad$ Perempuan &
\end{tabular}

$¥$ Uji Mann-Whitney

$£$ Uji Chi-square

\section{Gambaran laboratorium}

Gambaran pemeriksaan laboratorium sebelum mendapatkan perlakuan tertera pada Tabel 2 .

Nilai rerata gula darah sewaktu (GDS) sebelum intervensi pada kelompok suplementasi madu lebih tinggi yaitu 89,09 $( \pm 1,6328)$ dibandingkan dengan kelompok tanpa suplementasi madu 86,86 $( \pm 1,83)$. Sedangkan untuk rerata GDS akhir pada kelompok suplementasi madu sedikit lebih tinggi $96,77( \pm 1,46)$ dibandingkan dengan kelompok tanpa suplementasi madu 96,0286 $( \pm 1,50)$. Selengkapnya tertera pada Tabel 3.

\section{Lama rawat}

Rerata lama rawat kelompok suplementasi madu lebih pendek yaitu 59,46 $( \pm 3,89)$ jam dibandingkan kelompok tanpa suplementasi madu 71,20 $( \pm 3,89)$ jam (Tabel 4).

Tabel 2. Hasil pemeriksaan laboratorium

\begin{tabular}{lcccccc}
\hline \multirow{2}{*}{$\begin{array}{l}\text { Pemeriksaan } \\
\text { laboratorium }\end{array}$} & \multicolumn{3}{c}{$\begin{array}{c}\text { Suplementasi madu } \\
(\mathrm{n}=35)\end{array}$} & \multicolumn{3}{c}{$\begin{array}{c}\text { Tanpa suplementasi madu } \\
(\mathrm{n}=35)\end{array}$} \\
\cline { 2 - 7 } & Min & Maks & Rerata & Min & Maks & Rerata \\
\hline Hemoglobin $(\mathrm{g} / \mathrm{dl})$ & 9,5 & 13,1 & $11,47 \pm 0,15$ & 6,2 & 13,6 & $11,19 \pm 0,24$ \\
Hematokrit $(\mathrm{vol} \%)$ & 31,0 & 39,9 & $35,06 \pm 0,44$ & 21,0 & 40,6 & $34,55 \pm 0,72$ \\
Leukosit $(/ \mathrm{dl})$ & 5,93 & 16,30 & $10,11 \pm 0,456$ & 5,10 & 19,20 & $10,23 \pm 0,568$ \\
Trombosit $(/ \mathrm{dl})$ & 127 & 649 & $345,40 \pm 15,787$ & 158 & 542 & $334,77 \pm 16,096$ \\
\hline
\end{tabular}

$¥$ Uji Mann-Whitney

$\$$ t-test

Tabel 3. Hasil pemeriksaan gula darah sewaktu sebelum dan sesudah pemberian suplementasi

\begin{tabular}{|c|c|c|c|c|c|c|c|}
\hline \multirow[t]{2}{*}{ Kadar gula darah sewaktu } & \multicolumn{3}{|c|}{$\begin{array}{l}\text { Suplementasi madu } \\
\qquad(\mathrm{n}=35)\end{array}$} & \multicolumn{3}{|c|}{$\begin{array}{l}\text { Tanpa suplementasi madu } \\
\qquad(\mathrm{n}=35)\end{array}$} & \multirow[t]{2}{*}{$\mathrm{p}$} \\
\hline & Min & Maks & Rerata & Min & Maks & Rerata & \\
\hline Awal (mg/dL) & 74 & 111 & $89,09 \pm 1,63$ & 66 & 110 & $86,86 \pm 1,83$ & $0,367^{\$}$ \\
\hline Akhir (mg/dL) & 79 & 124 & $96,77 \pm 1,46$ & 80 & 111 & $96,03 \pm 1,50$ & $0,981^{¥}$ \\
\hline
\end{tabular}

$\$$ t-test

$¥$ Uji Mann-Whitney

Tabel 4. Rerata lama rawat

\begin{tabular}{lccccc}
\hline Kelompok & $\begin{array}{c}\text { Minimal } \\
(\mathrm{jam})\end{array}$ & $\begin{array}{c}\text { Maksimal } \\
(\mathrm{jam})\end{array}$ & $\begin{array}{c}\text { Rerata } \\
(\mathrm{jam})\end{array}$ & $\begin{array}{c}\text { Simpangan } \\
\text { baku (jam) }\end{array}$ & IK 95\% \\
\hline Suplementasi madu & 19 & 105 & 59,46 & 3,89 & $-11,74$ \\
Tanpa suplementasi madu & 35 & 119 & 71,20 & 3,89 & $(-22,71 ;-0,77)$ \\
\hline
\end{tabular}

$p=0,036^{*} ; ¥ \mathrm{t}$-test 


\section{Analisis kesintasan (survival analysis) lama rawat}

Median lama rawat kelompok suplementasi madu 3 hari sementara pada kelompok tanpa suplementasi madu 4 hari. Berdasarkan test dari persamaan distribusi

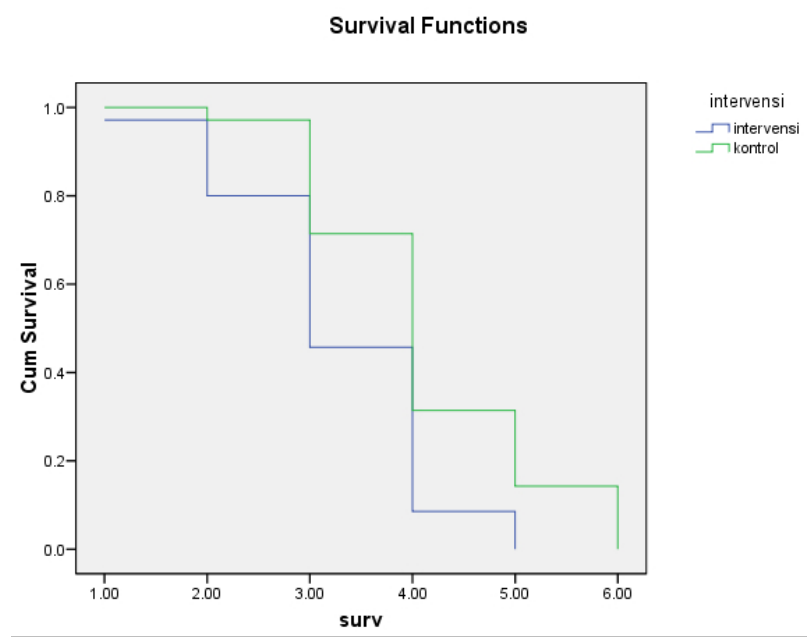

Gambar 1. Pola fungsi kesintasan lama rawat pada kedua kelompok penelitian kesintasan untuk lama rawat pada kelompok subyek penelitian (Log Rank, Mantel-Cox) menunjukkan adanya perbedaan yang signifikan antara lama waktu rawat kelompok suplementasi madu dan kontrol ( $\mathrm{p}=0,001)$. Gambar 1 menunjukkan dengan analisa berdasarkan Kaplan-Meier, kelompok suplementasi madu yang mengalami kesembuhan 50\% terjadi pada perawatan hari ke-3, sementara pada kelompok kontrol 25\%.

\section{Kenaikan berat badan}

Tabel 5 menunjukkan proporsi anak yang mengalami peningkatan berat badan pada kelompok suplementasi madu sedikit lebih tinggi (82,9\%) dibanding kelompok tanpa suplementasi madu (80\%).

\section{Frekuensi diare}

Hasil analisis repeated measures memperlihatkan perbedaan yang signifikan $(\mathrm{p}<0,05)$ antara kelompok intervensi maupun kontrol terjadi pada hari ke-2,

Tabel 5. Status gizi anak pada kelompok penelitian

\begin{tabular}{|c|c|c|c|c|c|}
\hline \multirow{2}{*}{ Data antropometri } & \multicolumn{4}{|c|}{ Kelompok } & \multirow[b]{2}{*}{$\mathrm{p}$} \\
\hline & \multicolumn{2}{|c|}{$\begin{array}{l}\text { Suplementasi madu } \\
\qquad(\mathrm{n}=35)\end{array}$} & \multicolumn{2}{|c|}{$\begin{array}{l}\text { Tanpa suplementasi madu } \\
\qquad(\mathrm{n}=35)\end{array}$} & \\
\hline \multicolumn{2}{|c|}{ Tinggi badan $(\mathrm{cm}$, rerata, $\mathrm{SB})$} & $6 \pm 2,27$ & $79,71 \pm 1,07$ & & $0,819^{¥}$ \\
\hline \multicolumn{2}{|c|}{ Kenaikan berat badan, n, (\%) } & & & & $0,947^{\S}$ \\
\hline \multicolumn{2}{|l|}{ Tidak naik } & 14,3) & $6(17,1)$ & & \\
\hline \multicolumn{2}{|l|}{ Penurunan } & $(2,9)$ & $1(2,9)$ & & \\
\hline \multicolumn{2}{|l|}{ Peningkatan } & $(82,9)$ & $28(80)$ & & \\
\hline \multicolumn{2}{|l|}{ Status gi zi, n, (\%) } & & & & $0,798^{\S}$ \\
\hline \multicolumn{2}{|l|}{ Baik } & $(68,6)$ & $25(71,4)$ & & \\
\hline \multicolumn{2}{|l|}{ Kurang } & $(31,4)$ & $10(28,6)$ & & \\
\hline \multicolumn{6}{|l|}{$\begin{array}{l}¥ \text { Uji Mann Whitney } \\
\text { § Uji Chi-square }\end{array}$} \\
\hline \multicolumn{6}{|c|}{ Tabel 6. Frekuensi diare } \\
\hline \multirow[b]{2}{*}{ Hari perawatan } & \multicolumn{2}{|c|}{ Frekuensi diare (rerata, SB) } & & \multirow{2}{*}{\multicolumn{2}{|c|}{ IK 95\% }} \\
\hline & $\begin{array}{l}\text { Suplemen } \\
\text { madu }\end{array}$ & $\begin{array}{c}\text { Tanpa suplemen } \\
\text { madu }\end{array}$ & $\mathrm{p}$ & & \\
\hline 1 & $4,68 \pm 2,98$ & $4,83 \pm 2,80$ & 0,837 & 0,15 & $1,53 ; 1,24)$ \\
\hline 2 & $4,09 \pm 2,38$ & $5,63 \pm 3,13$ & $0,023^{*}$ & 1,54 & $2,87 ;-0,22)$ \\
\hline 3 & $2,83 \pm 2,50$ & $3,31 \pm 2,25$ & 0,396 & 0,48 & $1,62 ; 0,65)$ \\
\hline 4 & $0,94 \pm 1,24$ & $1,74 \pm 1,74$ & $0,030^{*}$ & 0,8 & $1,52 ;-0,08)$ \\
\hline 5 & $0,14 \pm 0,49$ & $0,66 \pm 1,30$ & $0,033^{*}$ & 0,52 & $0,99 ;-0,04)$ \\
\hline 6 & 0,00 & $0,14 \pm 0,43$ & & & \\
\hline
\end{tabular}


ke-4, dan ke-5. Namun apabila dilihat secara keseluruhan dari hari pertama sampai dengan hari ke enam, frekuensi diare pada kelompok intervensi dan kelompok kontrol tidak berbeda $(\mathrm{p}=0,072)$, seperti tertera pada Tabel 6 .

\section{Pembahasan}

Pemilihan usia subyek penelitian labih dari satu tahun, berdasarkan rekomendasi mencegah keracunan botulismus pada bayi, dengan tidak memberikan madu sampai usia 12 bulan. ${ }^{6,7}$ Berdasarkan hasil survei diare tahun 1990 di Kecamatan Beringin Kabupaten Semarang didapatkan kejadian diare tertinggi pada kelompok umur 6-24 bulan. ${ }^{8}$ Penelitian epidemiologi diare tidak menemukan perbedaan jenis kelamin pada insiden dan beratnya diare, sesuai dengan penelitian kami.

Widodo dari Pusat Penelitian dan Pengembangan Gizi Bogor melaporkan pada 51 balita usia 13-36 bulan yang diberi madu menunjukkan, tingkat morbiditas terhadap demam dan pilek kelompok madu menurun, nafsu makan meningkat, porsi dan frekuensi makan bertambah. Konsumsi energi dan protein mereka juga meningkat dibandingkan dengan kelompok kontrol yang mendapat sirup. Hasil penelitian kami, tidak menunjukkan perbedaan pada peningkatan berat badan. Hal ini dimungkinkan karena tidak dilakukan pengukuran jumlah asupan kalori harian pada subyek penelitian dan waktu pengamatan yang dilakukan berdasarkan lama rawat pada masing-masing kelompok terlalu pendek.

Kami tidak melibatkan keadaan status gizi buruk karena banyaknya faktor yang berpengaruh terhadap derajat sakit sehingga sulit disingkirkan sebagai faktor perancu. Malnutrisi mengakibatkan kerusakan barier mukosa sehingga meningkatkan kerentanan terhadap infeksi. Malnutrisi juga mengganggu produksi dan maturasi dari enterosit baru sehingga mengubah morfologi intestinal. ${ }^{9}$ Spektrum etiologi diare pada malnutrisi secara umum sama dengan yang ditemukan pada anak gizi baik tetapi dengan berkurangnya imunitas pada malnutrisi berat, kemungkinan terjadinya diare akibat kuman fakultatif patogen menjadi lebih besar. Demikian pula peran penyebab “ bukan infeksi" menjadi lebih besar. ${ }^{10}$

Hasil temuan pada penelitian kami menunjukkan bahwa pemberian suplementasi madu dapat mem- perpendek lama rawat $(59,46)$ jam pada kelompok intervensi dan 71,20 jam pada kelompok kontrol. Secara in vitro dan in vivo yang mengungkapkan efek antibakterial madu, seperti yang dilakukan oleh Haffejee dan Moosa ${ }^{4}$ yang meneliti efek madu untuk terapi gastroenteritis pada anak. Tigapuluh enam subyek dengan gastroenteritis bakteri, pada kelompok kontrol waktu penyembuhan 93,19 $(60,02)$ jam sedangkan pada kelompok perlakuan 58,00 $(34,54)$ jam yang berbeda bermakna secara statistik $(p<0,05)$. Ditinjau dari segi biaya perawatan kelas 3 di RS Dr. Kariadi pasien dengan diare akut cair tanpa komplikasi yang mendapatkan terapi standar kira-kira Rp.150.000/ hari, sehingga pemberian madu akan mengurangi biaya pearawatan.

Analisis kesintasan kesembuhan setelah perawatan kelompok suplementasi lebih cepat dibanding pada kelompok kontrol, mungkin karena madu memiliki aktivitas antimikroba melalui beberapa reaksi di antaranya rendahnya aktivitas air dalam madu, $\mathrm{pH}$ rendah, kandungan hidrogen peroksida, namun tidak ditemukannya penelitian yang meneliti secara langsung aktivitas tersebut terhadap diare akut, demikian juga terhadap perbedaan frekuensi diare.

Pengamatan dan uji statistik untuk frekuensi diare terdapat perbedaan pada hari ke-2, ke-4, dan ke-5. Pola penurunan jumlah frekuensi diare sejalan dengan lama diare, karena penyebab diare yang disebabkan karena infeksi rotavirus pada beberapa penelitian prevalensinya $30,4 \%-48,8 \%{ }^{9,11}$ merupakan kelainan yang bersifat sembuh sendiri (self limited desease) apabila tidak diperberat dengan kondisi imunitas yang menurun. Terjadinya perbedaan penurunan frekuensi diare pada kelompok suplementasi madu dibanding kelompok yang tidak mendapatkan suplementasi madu, peneliti berasumsi berdasarkan kemampuan madu untuk membantu terbentuknya jaringan granulasi. Memperbaiki kerusakan permukaan kripte usus dan adanya efek madu sebagai prebiotik yang dapat menumbuhkan kuman komensal dalam usus dengan kemampuan melekat pada enterosit mukosa usus sehingga dapat menghambat kolonisasi sejumlah bakteri penyebab diare termasuk virus (murine dan rhesus rotavirus). ${ }^{12,13,14}$

Pembentukan NO di dalam saluran cerna yang dapat merelaksasi otot polos sehingga akan menurunkan motilitas usus dan berfungsi pula sebagai vasodilator. Hal tersebut dapat meningkatkan aliran darah dalam saluran cerna sehingga dapat mempercepat proses 
perbaikan kerusakan permukaan kripte usus. Maka perlu dilakukan penelitian lebih lanjut berkaitan dengan kandungan dan efek yang ditimbulkan oleh pembentukan NO dalam saluran cerna. ${ }^{15,16}$ Peneliti belum dapat menjelaskan kenapa terjadi peningkatan frekuensi diare pada pengamatan perawatan hari ke-2 pada kelompok tanpa suplementasi madu.

Beberapa keterbatasan penelitian antara lain penelitian tidak dilaksanakan secara tersamar ganda karena adanya keterbatasan dalam mengkoordinir tenaga yang memberikan perlakuan dan pengamatan terhadap subyek penelitian, tidak dilakukan pengukuran volume feses sehingga tidak dapat dinilai perbedaan berat diare, pengamatan kenaikan berat badan yang kurang lama serta pencatatan jumlah asupan gizi tidak dilakukan. Tidak dilakukannya penelusuran kandungan dan jenis tanaman, karena menurut berberapa kepustakaan kandungan dan manfaat madu tergantung dari jenis tanaman yang menjadi sumber utama lebah dalam memproduksi madu. Tidak dianalisis lama diare sebelum masuk perawatan karena orang tua atau pendamping subyek umumnya tidak mengetahui secara pasti kapan mulai terjadi diare. Sehingga apabila dilakukan analisis akan menimbulkan bias, check list sebagai data awal pada subyek penelitian tidak mencatat secara lengkap dan rinci diet dan pengobatan baik medis maupun tradisional yang diberikan pada saat diare sebelum pengamatan pada penelitian ini. Pemberian suplementasi madu pada terapi standar pasien diare akut, disimpulkan terbukti menurunkan frekuensi diare pada perawatan hari ke 2 , 4, dan 5. Pemberian suplementasi madu pada terapi standar pasien diare akut, terbukti memperpendek lama rawat.

\section{Daftar pustaka}

1. Pemerintah Provinsi Jawa Tengah Dinas Kesehatan. Profil kesehatan Provinsi Jawa Tengah tahun 2004. 2006 [Diakses pada 25 April 2008]. Didapat dari:_http://www. health-lrc.or.id/profil2004/bad4.htm\#1

2. Departemen Kesehatan RI. Profil kesehatan Indonesia 2006. 2007 [Diakses pada 26 Maret 2008]. Didapat dari: http://www.depkes.go.id/downloads/publikasi/Profil Kesehatan Indonesia 2006.pdf

3. Jeffrey AE, Echazarreta CM. Medical uses of honey. Rev Biomed 1996; 7: 43-49. [Diakses pada tanggal 13 Maret 2008]. Didapat dari: http://www.uady.mx/-biomedicl revbiomed/pdflrb96716.pdf

4. Haffejee IE, Moosa A. Honey in the treatment of infantile gastroenteritis. Br Med J 1985;290:1866-7. [Diakses pada tanggal 13 Maret 2008]. Didapat dari:http://www.pubmedcentral.nih.gov/picrender.fcgi?artid= $1416773 \&$ oblobtype $=p d f$

5. Kajiwara S, Gandhi H, Ustunol Z. Effect of honey on the growth of and acid production by human intestinal Bifidobacterium spp. An in vitro comparison with commercial oligosaccharides and inulin. J Food Prot 2002; 65: 214-8.

6. Puspitasari I. Rahasia sehat madu. Yogyakarta: B First, Juli 2007.

7. Arnon SS. Infant botulism. [Diakses pada April 2009]. Didapat dari: http://www.infantbotulism.org/readings/ibchap. $p d f$

8. Sudigbia I. Pengaruh suplementasi tempe terhadap kecepatan tumb uh pada pasien diare anak umur 6-24 bulan [Disertasi]. Semarang: Universitas Diponegoro; 1990:7-37.

9. Brewster David R. Intestinal permeability in proteinenergy malnutrition. Dalam: Zulfikar Ahmed Bhutta, penyunting. Contemporary issues in childhood diarrhoea and malnutrition. Pakistan: Oxford University Press; 2000.h.126-79.

10. Kleinman RE. Persistent Diarrheal Disease. Dalam: Pediatric Nutrition Handbook. Edisi ke-4. Elk Grove Village, IL: American Academy of Pediatrics; 1998.h.33749.

11. Suheryati, Azhali M.S., Yasmar A, Sumarna N. Prevalensi infeksi rotavirus pasien diare akut pada anak usia 1-60 bulan di Puskesmas kota Bandung. Kumpulan makalah Kongres Nasional II Badan Koordinasi Gastroenterology anak Indonesia (BKGAI) di Bandung, 2003 July 3-5. Bandung, BKGAI: 361.

12. Ali ATM. Natural honey accelerates healing of indomethacin-induce antral ulcers in rats. Saudi Med J 1995;16:161-6.

13. Sudarmo SM. Peranan probiotik dan prebiotik dalam upaya pencegahan dan pengobatan diare pada anak. Kumpulan makalah kongres nasional II badan koordinasi gastroenterology anak Indonesia (BKGAI) di Bandung, 2003 July 3-5. Bandung, BKGAI:115-31.

14. Rastall R.A. Bacteria in gut: friends and foes and how to alter the balance. America Society for Nutritional Sciences. J. Nutr 2004;134:2022S-6S [Diakses pada tanggal 26 Maret 2008]. Didapat dari: $\underline{\mathrm{h} t t p: / / j n . n u t r i t i o n .}$ org/cgi/reprint/134/8/2022S

15. Beretta G, Gelmini F, Lodi V, Pizzalunga A, Facino 
R.M. Profile of nitric oxide (NO) metabolites (nitrate, nitrite and $\mathrm{N}$-nitroso groups) in honeys of different botanical origins: nitrate accumulation as index of origin, quality and therapeutic opportunities. J Pharm Biomed Anal 2010;53:343-9. [Diakses pada Agustus 2010]; Didapat dari: http://www.sciencedirect. com/science?_ob=MImg\&_imagekey=B6TGX-4YVY736-

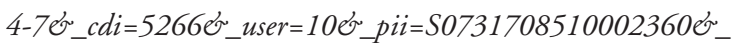
orig=browse\&_coverDate $=11 \% 2 \mathrm{F02} \% 2 \mathrm{~F} 2010 \mathrm{~d}$ $s k=999469996 \delta$ view $=c$ \& $w \mathrm{ch} p=d G L z V l b-z S k$ Wbo $m d 5=9 d$ 879ec8faca605c5cb4ec8323c6f4d06rie=/sdarticle.pdf

16. Kartasasmita R.E. Perkembangan obat anti radang bukan steroid. Acta Pharmaceutica Indonesia 2002;27:7591. 